\title{
EXPLOITATION OF Erythrina dominguezii Hassl. (Fabaceae) NECTAR BY PERCHING BIRDS IN A DRY FOREST IN WESTERN BRAZIL
}

\author{
RAGUSA-NETTO, J. \\ Departamento de Ciências Naturais, Universidade Federal do Mato Grosso do Sul, Campus Três Lagoas, \\ C. P. 210, CEP 79600-000, Três Lagoas, MS, Brazil \\ Correspondence to: José Ragusa-Neto, Departamento de Ciências Naturais, Universidade Federal do Mato Grosso \\ do Sul, Campus Três Lagoas, C. P. 210, CEP 79600-000, Três Lagoas, MS, Brazil, e-mail: forpus@ @eul.ufms.br \\ Received September 19, 2001 - Accepted November 30, 2001 - Distributed November 30, 2002
}

(With 1 figure)

\begin{abstract}
Among the vertebrate pollinated plants, the genus Erythrina includes tree species in which birds are the pollen vectors. Two groups in this genus may be distinguished: a) the hummingbird, and b) the perching bird pollinated species. Erythrina dominguezii is included in the second group and occurs in deciduous/semi-deciduous forests in the southwestern neotropics. I studied the exploitation of Erythrina dominguezii nectar by perching birds in a dry forest in western Brazil. Six perching bird species from two distinct groups (Psittacidae: Brotogeris chiriri, Nandayus nenday, Aratinga acuticaudata; Icterinae: Psarocolius decumanus, Icterus cayanensis, I. icterus) consumed its nectar. The two most important consumers were Brotogeris chiriri (51.5\% of the flowers visited by birds) and Psarocolius decumanus (20\%). While B. chiriri was a flower predator, P. decumanus removed the nectar without damaging the flowers which it opened by inserting its large bill between the standard and the keel. Nandayus nenday, Aratinga acuticaudata, and I. icterus exploited the nectar like $P$. decumanus, and presumably also contributed to pollen transfer. As the flowering in $E$. dominguezii was intense and synchronous during the dryest period of the year, and its nectar was highly consumed by birds, the present data suggest that the nectar of this species may be important as an alternative resource to frugivorous/omnivorous birds when other resources are scarce.
\end{abstract}

Key words: bird pollination, parakeets, Icterinae, nectar exploitation, Erythrina.

\section{RESUMO}

\section{Exploração de néctar em Erythrina dominguesii Hassl. (Fabaceae) por aves em uma mata seca do oeste brasileiro}

Dentre as plantas polinizadas por vertebrados, Erythrina inclui espécies arbóreas polinizadas por aves. Nesse gênero há dois grupos distintos: a) o de espécies polinizadas por beija-flores e b) o de espécies polinizadas por aves que não os beija-flores. Erythrina dominguezii está incluída no segundo grupo e é comum em matas decíduas e semidecíduas do sudoeste neotropical. Foi estudada a exploração de néctar em Erythrina dominguezii por aves em uma mata seca do oeste brasileiro. Seis espécies de aves de dois grupos distintos (Psittacidae: Brotogeris chiriri, Nandayus nenday, Aratinga acuticaudata; Icterinae: Psarocolius decumanus, Icterus cayanensis, I. icterus) consumiram o néctar dessa espécie arbórea. As duas espécies com maior consumo de néctar foram $B$. chiriri $(51,5 \%$ das flores visitadas pelas aves) e P. decumanus (20\%). Enquanto B. chiriri atuou como predador de flores, $P$. decumanus inseria seu grande bico entre o estandarte e a carena para abrir as flores e acessar o néctar, sem danificá-las. Dessa forma, $P$. decumanus potencialmente é um importante polinizador de E. dominguezii. Nandayus nenday, Aratinga acuticaudata e I. icterus acessaram o néctar de forma 
similar a $P$. decumanus e presumivelmente contribuem para a polinização de E. dominguezii. A floração intensa nessa espécie arbórea foi aparentemente muito sincrônica durante o período mais seco do ano; além disso, o néctar das flores foi altamente consumido por aves. Assim, os dados deste estudo sugerem que o néctar de E. dominguezii pode ser uma alternativa alimentar importante para as aves frugívoras/ onívoras quando houver escassez de outros recursos.

Palavras-chave: polinização por aves, periquitos, Icterinae, consumo de nectar, Erythrina.

\section{INTRODUCTION}

Nectar may be a valuable resource for frugivorus/omnivorous birds mainly in highly seasonal habitats when resources such as fleshy fruits are scarce (Pettet, 1977; Cannon, 1984; Terborgh, 1986). Typically, leaf loss is intense in seasonal habitats from the middle to end dry season (Leigh \& Windsor, 1982; Terborgh, 1983; Ferrari $\&$ Strier, 1992). Thus, the conspicuousness of flowering crowns is enhanced, and they may be visited by a large and diverse assemblage of birds (Toledo, 1977; Morton, 1979; Feisinger et al., 1979). Plants from the genus Erythrina are well known for producing nectar rich bird-pollinated flowers (Feisinger et al., 1979; Hernández \& Toledo, 1979; Morton, 1979; Raven, 1977; Steiner, 1979; Toledo, 1977; Toledo \& Hernández, 1979). The inflorescences of hummingbird-pollinated species are held upright, the flowers are arranged radially along the axis, and the narrow standard petal is conduplicately folded to form a pseudotube. In most of passerine-pollinated species, the inflorescences are held horizontally, the flowers are second, and the standard petal is open so that the nectar and androecium are easily visible and accessible. Nectar and amino acid concentrations and sucrose-to-hexose ratios are closely associated with pollination mode (Bruneau, 1997).

Erythrina dominguezii Hassl. (Fabaceae) is a middle-to-large tree species common in deciduous/ semi-deciduous forests of western Brazil (Neill, 1988; Pott \& Pott, 1994). Its flower structure falls into that of the passerine-pollinated species, and flowering includes thousands of flowers when the crown is leafless. Also, the flowering in E. dominguezii occurs in the dry season middle-to-end (August-September), a period of intense leaf-loss for most trees. This fact enhances the conspicuousness of E. dominguezii, which serves as an important nectar source. In this study, I examined nectar consumption by birds in E. dominguezii during the 1998 dry season and evaluated the potential role for birds as pollen vectors.

\section{METHODS}

\section{Study area}

This study was carried out in a dry forest $\left(19^{\circ} 05^{\prime} \mathrm{S}\right.$ and $57^{\circ} 36^{\prime} \mathrm{W}$, altitude $\pm 130 \mathrm{~m}$ ) near the city of Corumbá in the state of Mato Grosso do Sul. This site is part of a dry forest belt around Corumbá and includes flat and hilly terrain. Rainfall is around $800-1,000 \mathrm{~mm}$, with most rains $(600-800 \mathrm{~mm})$ concentrated in the wet season (from October to March). In the dry season (April to September) rainfall is approximately $200 \mathrm{~mm}$ or even less. Rainfall is uncommon in August, at which time $E$. dominguezii flowers (Pott \& Pott, 1994, pers. obs.). The mean annual temperature is $25^{\circ} \mathrm{C}$.

The canopy in this dry forest is $8-13 \mathrm{~m}$ in height and most trees (including E. dominguezii) are leafless from dry season middle-to-end. Common tree species here are Ceiba boliviana (Bombacaceae), Aspidosperma pyrifolium (Apocynaceae), Anadenanthera colubrina (Leguminoseae), Tabebuia impetiginosa (Bignoneaceae), Miracrodruon urundeuva (Anacardiaceae), Ficus calyptroceras (Moraceae), and Acrocomia aculeata (Arecaceae) (Ratter et al., 1988). The nine observed trees of E. dominguezii were at the edge of the dry forest, near pasturelands. Each tree was at least $300 \mathrm{~m}$ from the next.

\section{Field procedures}

In August 1998 I looked for flowering $E$. dominguezii at the edge of the dry forests around Corumbá. The nine selected trees (DBH from 48 to $106 \mathrm{~cm}$ ) were suitable for observations since their crowns were easily observed and bore thousands of flowers. Before studying each tree I estimated the number of flowers, following Chapman et al. (1992). Each tree was observed once from 7:00 to 12:00 $\mathrm{h}$ in the period between 7 and 24 August 1998, totaling $45 \mathrm{~h}$ of direct observation. During the observation period I recorded: a) the time birds entered and left the crown, b) number of birds per species visiting the 
tree simultaneously, c) whenever possible I recorded for the most accessible bird of each species the number of flowers exploited in one minute, and d) the way birds removed the nectar.

I observed birds foraging on flowers of $E$. dominguezii with the aid of $8 \times 30$ binoculars. Observations were dictated into a portable recorder for later transcription. In mid-August I evaluated nectar availability and concentrations in three trees. At the beginning of every hour (from 7:00 to 11:00 h) I removed 10 flowers from each tree and measured the nectar volume (with a microsyringe) and concentration (with a hand refractometer). I also collected 30 flowers from five trees to measure floral part structure (with the aid of a digital caliper).

I estimated the number of flowers exploited by each bird species using the following calculations: (number of visits) $x$ (mean time of visits) $x$ (mean number of flowers exploited per minute). Birds were assumed to be nectar robbers if they removed the nectar by piercing the calyx or the standard and the keel. They were considered flower predators if they removed the flowers to feed on the nectar and discarded then under the crown. The birds that inserted their bill and head between the standard and the keel to open the flowers in order to remove the nectar were presumably potential pollinators, since they probably contacted the anthers and the stigma. Statistical procedures followed Sokal \& Rohlf (1981).

\section{RESULTS}

All trees bore thousands of flowers during the observation periods. The largest tree bore an estimated 42,000 flowers, the smallest 7,000. One tree had 11,000 flowers; two 13,000; one 14,000; one 15,000; one 19,000; and another 24,000. The flowers of $E$. dominguezii hung by a pedicel whose length (mean $\pm \mathrm{sd}$ ) was $50.9 \pm 6.7 \mathrm{~mm}$. The calyx was $9.5 \pm 0.4 \mathrm{~mm}$ long, $14.3 \pm 0.5 \mathrm{~mm}$ wide, and $7.3 \pm 0.3 \mathrm{~mm}$ thick. The obovate standard that enclosed the other floral parts was $41.5 \pm 1.7 \mathrm{~mm}$ long and $15.7 \pm 1.1 \mathrm{~mm}$ wide. The flowers were pale orange-pink in color.

The mean nectar volume was similar in the flowers sampled at different hours. Mean volume in the first sample $(7: 00 \mathrm{~h})$ was slighter smaller than that of the last sample (11:00 h, Table 1). Nectar concentration was almost uniform among the samples. In all cases, concentration was around $20 \%$ (Table 1). Six bird species were recorded feeding on nectar of flowers of E. dominguezii. Although hummingbirds are common nectar consumers of Erythrina, no bird of this group was recorded exploiting its nectar. Perching birds from two families (Psittacidae: Brotogeris chiriri, Nandayus nenday, and Aratinga acuticaudata; Emberizidae: Psarocolius decumanus, Icterus cayanensis, and I. icterus) were the consumers of $E$. dominguezii nectar. In two trees (11,000 and 13,000 flowers) three bird species were recorded feeding on nectar; in four trees (one bore 7,000 flowers; one 13,000; one 14,000; and one 19,000 flowers) four species exploited the nectar, and in three trees $(15,000 ; 24,000$; and 42,000 flowers) six bird species consumed the nectar.

Except for the smallest tree, the number of bird species tended to be higher in trees richer in flowers. Brotogeris chiriri was recorded feeding on nectar in all studied trees, whereas $N$. nenday and $A$. acuticaudata were recorded in only three trees (one with 42,000 flowers; one with 24,000; and another with 13,000).

TABLE 1

Nectar availability and concentration in flowers of Erythrina dominguezii visited by birds in the morning $(\mathrm{N}=746$ visits by birds, and $\mathrm{N}=\mathbf{2 6 , 2 6 5}$ flowers exploited).

\begin{tabular}{|l|c|c|c|c|}
\hline \multicolumn{1}{|c|}{ Hour } & $\begin{array}{c}\text { Visits by birds } \\
(\boldsymbol{\%})\end{array}$ & $\begin{array}{c}\text { Flowers visited } \\
(\boldsymbol{\%})\end{array}$ & $\begin{array}{c}\text { Nectar volume } \\
\boldsymbol{\mu l}\end{array}$ & $\begin{array}{c}\text { Nectar concentration } \\
(\boldsymbol{\%})\end{array}$ \\
\hline 7:00-8:00 & 28 & 32 & $65 \pm 23$ & $20.6 \pm 1.5$ \\
\hline 8:00-9:00 & 26.5 & 20 & $64 \pm 09$ & $20.4 \pm 0.7$ \\
\hline 9:00-10:00 & 19 & 20 & $61 \pm 10$ & $20.3 \pm 1.2$ \\
\hline 10:00-11:00 & 20 & 20 & $62 \pm 12$ & $20.3 \pm 1.3$ \\
\hline 11:00-12:00 & 6.7 & 8 & $72 \pm 11$ & $20.0 \pm 0.9$ \\
\hline
\end{tabular}


The icterines were present in almost all trees. Both $P$. decumanus and I. icterus were absent from only one tree each $(13,000$ and 11,000 flowers, respectively). I. cayanensis was recorded feeding on nectar in all trees. The trees with higher numbers of flowers were the most visited $(r=0.74 ; p<0.05$; Pearson correlation, Fig. 1). The tree bearing 42,000 flowers received 229 visits whereas the one with 7,000 received only 35 . The proportion of flowers exploited decreased from the first to the last hour of observation (Table 1). While in the first hour $32 \%$ of the flowers were visited, less than $8 \%$ were visited in the last (Table 1 ).

Parakeets were the most important nectar consumers. Although $N$. nenday and A. acuticaudata were recorded feeding on nectar in only three trees, parakeets visited trees in flocks and averaged 10 min. or more per visit (Table 2). In some cases I recorded visits of longer than $20 \mathrm{~min}$. by more than 10 parakeets. B. chiriri was the major consumer of E. dominguesii nectar. This small parakeet exploited $51.5 \%$ of the visited flowers (an estimated 26,265 exploited flowers) and was also the major nectar consumer in all trees observed. To remove the nectar, B. chiriri took each flower with their bills, detached it from the pedicel, and pierced the calyx to drink the nectar. After that they discarded the flowers under the crown. Although smaller than the two other species of parakeets, $B$. chiriri probably did not transfer pollen in E. Dominguezii. But $N$. nenday and A. acuticaudata inserted their jaws between the standard and the keel opening of the flower to drink the nectar and by doing so touched their cheeks to the anthers and the stigma. Unlike B. chiriri, these species potentially contributed to pollination of $E$. dominguezii. Among the icterines, $P$. decumanus was the most important nectar consumer. This large passerine visited the trees in pairs or groups and averaged 5-10 min. per visit (Table 2). It exploited $20 \%$ of the visited flowers and showed a pattern of nectar consumption that suggested a pollinator role. To obtain the nectar, $P$. decumanus took the flowers with its bill and held them on the branch with the aid of one foot. Then the bird inserted its large bill between the standard and the keel, opened it to open the flower, and drank the nectar. As the bill was being inserted between the petals, it presumably contacted the anthers and stigma.

The two other species of icterines were less remarkable as nectar consumers (Table 2). One of them, I. cayanensis, in $92.5 \%$ of its visits to flowers was a nectar robber, since it pierced the petals to remove the nectar. In $7.5 \%$ of its visits it obtained the nectar in the same way as $P$. decumanus. I. icterus showed an inverse pattern in relation to I. cayanensis. In $93.7 \%$ of its visits, it inserted the bill between the petals to remove the nectar as $P$. decumanus did. I. icterus robbed nectar very few times. Thus, as I. icterus exploited $8 \%$ of the flowers visited, and most of its visits potentially resulted in contact with the pollen and the stigma (in many instances these birds were observed with their black faces dirty), it presumably contributed to pollination in E. dominguezii.

TABLE 2

The exploitation of Erythrina dominguezii flowers $(\mathrm{N}=\mathbf{2 6 , 2 6 5 )}$ during visits $(\mathrm{N}=746)$ by birds.

\begin{tabular}{|c|c|c|c|c|c|}
\hline Species & $\begin{array}{c}\text { Flowers } \\
\text { visited }(\%)\end{array}$ & $\begin{array}{l}\text { Visits } \\
(\%)\end{array}$ & $\begin{array}{l}\text { Mean }( \pm \mathrm{sd}) \\
\text { group size }\end{array}$ & $\begin{array}{l}\text { Mean time of } \\
\text { visits (min) }\end{array}$ & $\begin{array}{c}\text { Mean number of } \\
\text { flowers visited }(1 \mathrm{~min})\end{array}$ \\
\hline \multicolumn{6}{|l|}{ Psittacidae } \\
\hline Brotogeris chiriri & 51.5 & 42 & $3.5 \pm 2.7$ & $12.6 \pm 11.7$ & $6.8 \pm 3.6(82)^{*}$ \\
\hline Nandayus nenday & 12.8 & 12.5 & $3.7 \pm 2.0$ & $9.9 \pm 5.9$ & $6.9 \pm 2.5(37)$ \\
\hline Aratinga acuticaudata & 7.0 & 3 & $4.6 \pm 3.1$ & $19.9 \pm 12.6$ & $5.3 \pm 2.2(17)$ \\
\hline \multicolumn{6}{|l|}{ Icterinae } \\
\hline Psarocolius decumanus & 20.0 & 23 & $1.7 \pm 1.3$ & $8.4 \pm 6.1$ & $6.4 \pm 4.0(64)$ \\
\hline Icterus icterus & 8.0 & 12 & $1.9 \pm 0.5$ & $7.0 \pm 4.4$ & $6.7 \pm 3.2(19)$ \\
\hline Icterus cayanensis & 3.0 & 7.5 & $1.8 \pm 0.6$ & $6.9 \pm 3.8$ & $4.0 \pm 2.8(32)$ \\
\hline
\end{tabular}

* In brackets, the sample size for flowers exploited per minute. 


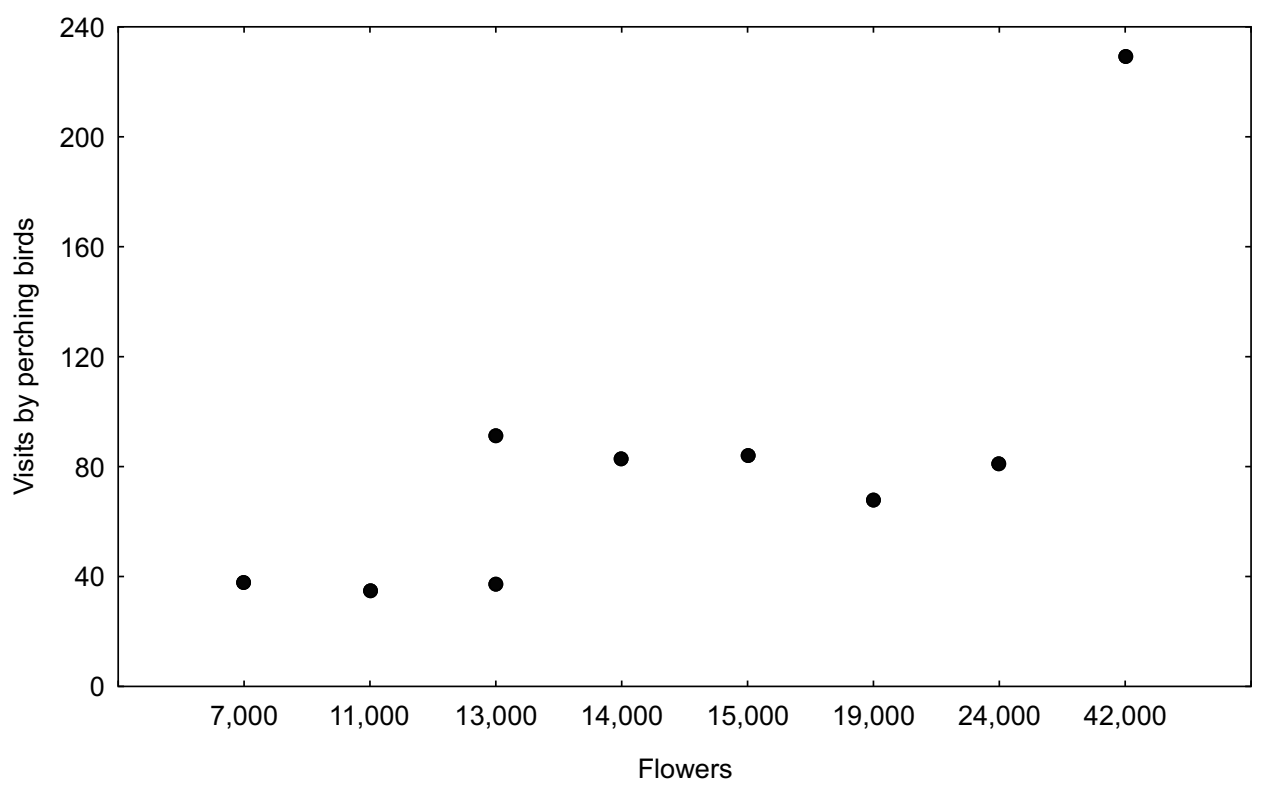

Fig. 1 - The number of visits by perching birds $(\mathrm{N}=746)$ as a function of the flower number in trees $(\mathrm{N}=9)$ of Erythrina dominguezii in a dry forest in western Brazil.

\section{DISCUSSION}

In many species of Erythrina the consumption of nectar by passerines has been well documented. Besides being nectar consumers, passerines are their pollinators (Feinsinger et al., 1979; Morton, 1979; Steiner, 1979; Toledo \& Hernández, 1979). Passerine pollinated species of Erythrina commonly produce copious nectar whose concentration is around $20 \%$ and which is consumed by birds able to open the flowers (Feinsinger et al., 1979; Morton, 1979; Toledo \& Hernandez, 1979).

Icterines have been recorded as the major nectar consumers as well as pollinators of Erythrina studied elsewhere (Morton, 1979; Toledo \& Hernández, 1979). In Panama, Icterus spurius was the pollinator of E. fusca (Morton, 1979) whereas in Mexico, I. sclateri and I. wagleri were the main pollinators of E. oliviae (Toledo \& Hernández, 1979). I. cayanensis and $I$. icterus recorded feeding on nectar of $E$. dominguezii differed in their ways of accessing it. While I. icterus probably contributed to pollen transfer, I. cayanensis was mainly a nectar robber. However, as the total of flowers exploited by both species was $11 \%$, the exploitation of E. dominguezii by birds of the genus Icterus was not as remarkable as in the cases cited above.

In this study, the most important nectar consumer among the icterines was the large Psarocolius decumanus which was also recorded visiting flowers of E. poeppigiana and E. fusca in Trinidad and Tobago (Feinsinger et al., 1979). However, in both species $P$. decumanus was among the least frequent visitors. This bird species continues abundant in the dry forests around Corumbá (pers. obs.). Furthermore, it was recorded foraging in almost all observed E. dominguezii, always inserting its bill between the standard and the keel to open the flowers for nectar removal without damaging them. Thus, apparently $P$. decumanus is the most important pollen vector in E. dominguezii.

The enormous consumption of nectar by parakeets in E. dominguezii has been uncommon among the species of this genus (Feinsinger et al., 1979; Morton, 1979; Steiner, 1979; Toledo \& Hernández, 1979). In Panama, Brotogeris jugularis was shown to be a minor nectar robber in Erythrina fusca (Morton, 1979), while in Tobago Amazona amazonica ate some flowers of E. poeppigiana (Feinsinger et al., 1979). 
Parrots and parakeets are well-known seed predators (Jansen, 1981; Coates-Estrada et al., 1993). As Brotogeris chiriri damages flowers from $E$. dominguezii to exploit the nectar, it may be considered an important pre-dispersal seed predator, since this parakeet was by far the most important nectar consumer. Nevertheless, Nandayus nenday and Aratinga acuticaudata exploited the flowers from E. dominguezii without damaging them. In fact, both species of parakeets showed a pattern of nectar consumption which suggests their potential role as pollinators. In Australia and Southeast Asia, lories and lorikeets (whose tongues are specialized for pollen and nectar feeding) are the pollinators of several plant species (Brown \& Hopkins, 1995), and the nectar is a major dietary component (Cannon, 1984; Forshaw, 1989; Brown \& Hopkins, 1995). In the neotropics, only recently parakeets have been recorded as pollinators of canopy trees (Maués \& Venturieri, 1996; Vicentini \& Fischer, 1999). Although $N$. nenday and A. acuticaudata were recorded in few trees, they visited trees in flocks for periods longer than $10 \mathrm{~min}$. Thus, they presumably transfer the pollen of many flowers (they exploited $17.5 \%$ of the flowers visited), contributing to pollination in E. dominguezii.

The flowering in E. dominguezii occurs at a time of year when typically there is no rainfall and few available resources such as fruit (pers. obs., in an ongoing study on flower and fruit phenology in a dry forest near Corumbá). The flowering in E. dominguezii is apparently very synchronous, since the nine observed trees as well as many others in the area had flowers in August 1998 (observation supported by the ongoing study cited above). Thus, the intense nectar consumption by birds in E. dominguezii, especially by $B$. chiriri, suggests that this plant is an important resource for birds including nectar in their diet. The use of nectar in periods of resource scarcity as an alternative by vertebrates other than hummingbirds and nectarivorous bats has been found in some studies in tropical forests (Terborgh, 1986; Terborgh \& Stern, 1987; Gryjl et al., 1990; Ferrari \& Strier, 1992). Thus, the abundant nectar produced by E. dominguezii could contribute to the persistence of frugivorous/omnivorous birds recorded feeding on it in this dry forest. An ongoing study of plant resource availability and its consumption by frugivorous birds is pointing out this role of E. dominguezii.
Acknowledgments - I am grateful to PROPP (UFMS) for financial support and Vanda Lúcia Ferreira for field assistance. Comments of an anonymous reviewer improved the manuscript. Regina Baruki Fonseca improved the English.

\section{REFERENCES}

BROWN, E. D. \& HOPKINS, J. C., 1995, A test of pollinator specificity and morphological convergence between nectarivorous birds and rainforest tree flowers in New Guinea. Oecologia, 103: 89-100.

BRUNEAU, A., 1997, Evolution and homology of bird pollination syndromes in Erythrina (Leguminosae). Am. J. Bot., 84: 54-71.

CANNON, C. E., 1984, The diet of lorikeets Trichoglossus spp. In the Queensland-New South Wales border region. Ети, 84: 16-22.

CHAPMAN, C. A., HUNT, K. \& GEBO, D., 1992, Estimators of fruit abundance of tropical trees. Biotropica, 24: 527-531.

COATES-ESTRADA, R., ESTRADA, A. \& MERRIT JR., D., 1993, Foraging by parrots (Amazona autumnalis) on fruits of Stemmadenia donnell-smithii (Apocynaceae) in the tropical rain forest of Los Tuxtlas, Mexico. J. Trop. Ecol., 9: 121-124.

FEINSINGER, P., LINHART, Y. B., SWARM, L. A. \& WOLFE, J. A., 1979, Aspects of the pollination of three Erythrina species on Trinidad and Tobago. Ann. Missouri Bot. Gard., 66: 451-471.

FERRARI, S. F. \& STRIER, K. B., 1992, Exploitation of Mabea fistulifera nectar by marmosets (Callitrix flaviceps) and muriquis (Brachyteles arachnoides) in south-east Brazil. J. Trop. Ecol., 8: 225-239.

FORSHAW, J. M., 1989, Parrots of the world, 3rd edition. Lansdowne Editions, Willoughby, Australia.

GRYJL, E., MARTINEZ DEL RIO, C. \& BAKER, I., 1990, Avian pollination and nectar use in Combretum fruticosum (Loefl.). Biotropica, 22: 266-271.

HERNÁNDEZ, H. M. \& TOLEDO, V. M., 1979, The role of nectar robbers and pollinators in the reproduction of Erythrina leptorhiza. Ann. Missouri Bot. Gard., 66: 512-520.

JANSEN, D. H., 1981, Ficus ovalis seed predation by Orange-chinned Parakeet (Brotogeris jugularis) in Costa Rica. Auk, 98: 841-844.

LEIGH, E. G. \& WINDSOR, D. M., 1982, Forest production and regulation of primary consumers on Barro Colorado Island, pp. 111-112. In: E. G. Leigh, A. S. Rand \& D. M. Windsor (eds.), The ecology of a Tropical forest: seasonal rhythms and long-term changes. Smithsonian Institution Press, Washington D. C.

MAUÉS, M. M. \& VENTURIERI, G. C., 1996, Ecologia da polinização do bacurizeiro (Platonia insignis Mart.) Clusiaceae. Embrapa-CPATU, Boletim de Pesquisa 170, Belém, Brasil, 24p. 
MORTON, E. S., 1979, Effective pollination of Erythrina fusca by the orchard oriole (Icterius spurius): coevolved behavioral manipulation? Ann. Missouri Bot. Gard., 66: 482-489.

NEILL, D. A., 1988, Experimental studies on species relationships in Erythrina (Leguminosae: Papilionoideae). Ann. Miss. Bot. Gard., 75: 886-969.

PETTET, A., 1977, Seasonal changes in nectar-feeding by birds at Zaria, Nigeria. Ibis, 119: 291-308.

POTT, A. \& POTT, V., 1994, Plantas do Pantanal. Embrapa, Brasília, 320p.

RATTER, J. A., POTT, A., POTT, V. J., CUNHA, C. N. \& HARIDASAN, M., 1988, Observation on wood vegetation types in the Pantanal at Corumbá, Brazil. $N$. RBG. Edinb., 3: 503-525.

RAVEN, P. H., 1977, Erythrina symposium II. Erythrina (Fabaceae: Faboideae): Introduction to symposium II. Lloydia, 40: 401-406.

SOKAL, R. R. \& ROHLF, F. J., 1981, Biometry, $2^{\text {nd }}$ ed. W. H. Freeman, San Francisco.

STEINER, K. E., 1979, Passerine pollination of Erythrina megistophylla Diels (Fabaceae). Ann. Missouri Bot. Gard., 66: 490-502.
TERBORGH, J. \& STERN, M., 1987, The surreptitious life of the saddle-back tamarin. Amer. Sc., 75: 260-269.

TERBORGH, J., 1983, Five New World primates: a study in comparative ecology. Princeton University Press, Princeton, N.J.

TERBORGH, J., 1986, Keystone plant resources in the tropical forest. In: M. Soulé (ed.), Conservation biology. Sinauer, Sunderland, Massachussets.

TOLEDO, V. M. \& HERNÁNDEZ, H. M., 1979, Erythrina oliviae: a new case of oriole pollination in Mexico. Ann. Missouri Bot. Gard., 66: 503-511.

TOLEDO, V. M., 1977, Pollination of some rain forest plants by non-hovering birds in Veracruz, Mexico. Biotropica, 9: $262-267$

VICENTINI, A. \& FISCHER, E. A., 1999, Pollination of Moronobea coccinea (Clusiaceae) by the golden-winged parakeet in the central Amazon. Biotropica, 31: 692-696. 